\title{
Acute myeloradiculitis due to cytomegalovirus as the initial manifestation of AIDS
}

\author{
FLORENCE MAHIEUX, * FRANÇOISE GRAY, $\dagger$ GILLES FENELON, \\ ROMAIN GHERARDI, $\dagger$ DAVID ADAMS, ALAIN GUILLARD, JACQUES POIRIER $\dagger$ \\ From the Clinique Neurologique, Hôpital Tenon,* Paris, and the Département de Pathologie (Neuropathologie), \\ Hôpital Henri Mondor, $\dagger$ Créteil, France
}

SUMMARY A 26 year old male intravenous drug abuser presented with rapidly progressive paraplegia and total incontinence. CSF examination showed elevated protein level and pleocytosis. HIV testing was positive. Anti CMV titres were mildly elevated in serum and CSF. Death occurred 26 days after the onset of neurological signs. Necrotic and inflammatory lesions with numerous inclusion bodies characteristic of CMV were found in the roots of the cauda equina, conus terminalis and lumbar segments of the spinal cord. CMV subependymal encephalitis and HIV encephalitis were also present.

Cytomegalovirus (CMV) infection is one of the main criteria for the diagnosis of the Acquired Immunodeficiency Syndrome (AIDS) due to the human immunodeficiency virus (HIV). ${ }^{1}$ It is usually diffuse ${ }^{2}$ and in many cases is the immediate cause of death. ${ }^{3}$ CMV involvement of the nervous system usually produces encephalitis. ${ }^{4}$ This latter had been found in about $25 \%$ of CNS lesions in AIDS in a number of necropsy series. ${ }^{245}$

Since 1984 six cases of the so-called CMV "induced demylination" in the roots and spinal cord ${ }^{6}$ have been reported in AIDS patients with neurological symptoms referred to as "Guillain-Barré syndrome", "polyradiculopathy", "polyneuropathy", "spinal cord syndrome"10 and "polyradiculoneuropathy"." These cases were recently grouped together and classified by Dalakas and Pezeshkpour" as "progressive inflammatory polyradiculoneuropathies presenting as cauda equina syndrome".

The present paper describes a further clinicopathological case in which the neurological syndrome was the initial manifestation of AIDS.

Address for reprint requests: Dr F Mahieux, Clinique Neurologique, Hôpital Tenon, 4 Rue de la Chine, 75970 Paris, Cedex 20, France.

Received 2 February 1988 and in revised form 31 August 1988. Accepted 6 September 1988

\section{Case report}

A 26 year old intravenous drug abuser, Algerian male, was admitted to hospital with a 3 day history of lumbar pain (day 1), weakness of right leg (day 2) and urinary retention (day 3). Myelography was normal. CSF contained $441 \mathrm{mg} / \mathrm{dl}$ protein, $2.60 \mathrm{mmol} / 1$ glucose, $260 \mathrm{RBCs}$ and $500 \mathrm{WBCs}(70 \%$ polymorphs and $30 \%$ lymphocytes) $/ \mathrm{mm}^{3}$.

On admission, temperature was $38^{\circ} \mathrm{C}$ and mild lymphadenopathy was noted. The patient was alert and oriented. Examination of the cranial nerves and upper extremities was normal. Monoplegia with areflexia and diminished pinprick and position sense was observed in the right leg. Plantar responses were equivocal on the right and flexor on the left. Over a 10 day period the deficit extended to a complete flaccid paraplegia with bowel and bladder incontinence. CT of the brain and fundoscopy were normal. A second CSF sample (day 11) contained $170 \mathrm{mg} / \mathrm{dl}$ protein, $2.60 \mathrm{mmol} / 1$ glucose $55 \mathrm{RBCs}$ and $145 \mathrm{WBCs}(60 \% \mathrm{lym}$ phocytes, $25 \%$ polymorphs and $15 \%$ monocytes) $/ \mathrm{mm}^{3}$. Serum titres were $1 / 10.000$ for HIV, $1 / 160$ for CMV, and 1 / 6.400 for herpes simplex virus (HSV); CSF titres were $1 / 100$ for HIV, $1 / 8$ for CMV and $1 / 160$ for HSV. Tests were negative for $\mathrm{HBs}$ antigen (whereas $\mathrm{HBs}$ and $\mathrm{HBc}$ antibodies were positive) and cryptococcal antigen; VDRL, bacterial, fungal myobacterial cultures were negative. A biopsy of muscle and peripheral nerve performed at day 16; the specimen showed no significant changes on frozen, paraffin embedded or semi-thin sections and teasing preparations. Immunostaining for HIV was negative.

Subsequently the patient developed oral candidiasis; gastroscopy showed erythematous gastritis without oesophageal 

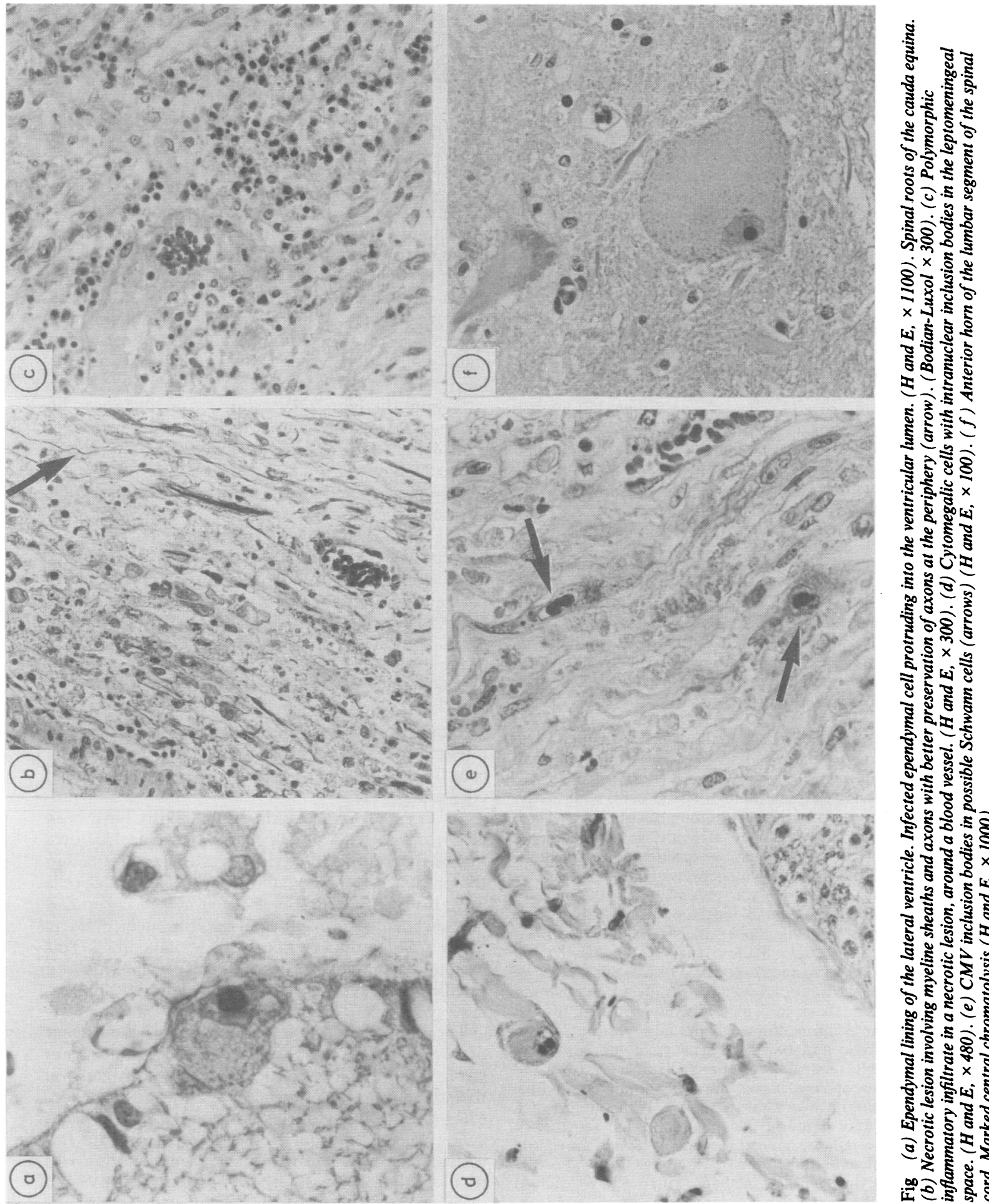

केष

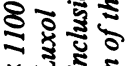

$\times$ 돈

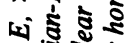

รี้ ถั้

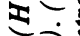

ริำ

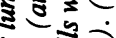

형요

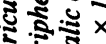

ป

ะ ㅇำ

: 0 บे

इ ริ)

औ్ㅀㅇ

ฐ

ธิธ

ㅊํㅇ

ชิำ

혼도

क्षे

ธั ฐั้

จัฐ

施

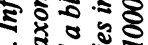

รั้ จิ

공ำ

ปิ

ธิ้

ฐ.

इั้

क०

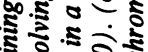

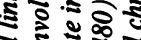

ฐ

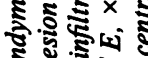

ํํㄴㄷำ

ชิ 원 논

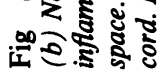


lesion. He became progressively drowsy. Untreatable hiccup appeared on day 18 , horizontal nystagmus in lateral gaze on day 21 and left facial paresis on day 24. Repeat CT of the brain was normal. Twenty-six days after onset of the illness the patient developed severe enterocolitis, became dehydrated, hypotensive and died.

\section{Pathological examination}

Post mortem examination was limited to brain, spinal cord and roots. On gross examination the brain weighed $1420 \mathrm{~g}$ and was externally normal. The leptomeningeal blood vessels were normal. Coronal slices showed greyish, ill defined discolouration of the hemispheric white matter most markedly in the parieto-occipital regions. The brainstem, cerebellum spinal cord and roots did not show significant changes.

Microscopical examination After fixation, blocks were taken from many regions of the cerebral hemispheres, cerebellum, brainstem, spinal cord, roots and ganglia and embedded in paraplast or in celloidin. Sections were stained with haematoxylin and eosin, Loyez stain for myelin, Masson trichrome and Bodian silver impregnation combined with Luxol fast blue. Immunostaining was performed on paraffinembedded specimens by the peroxidase-antiperoxidase (PAP) technique using a polyclonal antiserum raised against CMV (Polyscience, France).

Histological examination of the brainstem and cerebral hemispheres showed extensive loss of the ependymal lining, granular ependymitis and presence of microglial nodules in the subependymal layer. Large cytomegalic cells were present and some of them protruded into the ventricular lumen (fig, a). In addition, there was diffuse, ill defined pallor of the hemispheric white matter with reactive glial proliferation. Small subcortical foci of necrosis containing macrophages and occasional multinucleated giant cells, microglial nodules and mineralisation of blood vessels were suggestive of HIV encephalitis. $^{2}$

Severe changes were found in the caude equina and lower segment of the spinal cord and consisted of multiple small foci of recent necrosis involving roots and subpial regions of the conus medullaris and lumbar spinal cord, with myelin loss and severe reduction of the number of axons. These latter, however, appeared relatively spared at the periphery of the lesions (fig, b). Inflammatory reaction, which included neutrophils, plasma cells, lymphocytes and some histiocytes and macrophages (fig, c) was present within the areas of necrosis as well as around the blood vessels and in the leptomeninges; in the same areas CMV intranuclear inclusion bodies could be seen (fig, d). Though not all inclusion body containing cells could be identified, many of them had the features of Schwann cells (fig, e). In the lower segments of the spinal cord, most anterior horns cells showed marked central chromatolysis (fig, $\mathrm{f}$ ).

The thoracic and cervical segments of the cord were unremarkable. Examination of the spinal ganglia and extradural peripheral nerves did not show any necrotic, demyelinating or inflammatory change. No multinucleated giant cells were found in the spinal cord and roots; HSV inclusion bodies were not observed at any level of the central nervous system or in the roots.

Immunocytochemical methods for CMV stained positively the cytoplasm of large ependymal and sub- ependymal cells as well as some in the spinal roots and leptomeninges of the cauda equina and inferior part of the cord. No staining was observed in the deep white matter, basal ganglia, spinal ganglia and extradural part of the spinal roots.

\section{Discussion}

A variety of lesions of the central and/or peripheral nervous system have been described in patients with HIV infection. ${ }^{12-14}$ In the present case, rapidly progressive flaccid paraplegia could be related to necrotic and inflammatory lesions of the lower segments of the spinal cord and intra-dural lower spinal roots due to direct infection by the CMV. These features distinguish this myeloradiculopathy from Guillain-Barré syndromes secondary to immunological disorders of spinal roots and peripheral nerves, which have already been observed in AIDS patients. ${ }^{12} 1415$

Despite the high HSV serum titres, there was no evidence on the numerous specimens examined of concomitant HSV infection of the CNS as described by Yanagisawa et al ${ }^{16}$ and Tucker et al. ${ }^{17}$ Lesions of subacute encephalitis with multinucleated giant cells characteristic of HIV infection of the CNS were present in the hemispheric white matter but could not be observed in the cauda equina and spinal cord. Association of HIV and CMV infection in AIDS have been already described by Kleihues et al $^{18}$ who suggested a synergic action of these viruses at the origin of brain demyelinating lesions. Such a combined action of both viruses had also been proposed at the origin of demyelinating lesions of the peripheral nervous system. ${ }^{12}{ }^{14}$ However, since, in the present case, HIV infection appeared to be limited to the brain, it is possible that CMV infection involving the Schwann cells be sufficient per se to cause the lesions of spinal cord and roots. ${ }^{8}$

Six cases of CMV myeloradiculopathy have been reported since $1984^{6} 11$ with neuropathological features in spinal cord and roots similar to those described in the present case. CMV infection of ependymal cells was also observed by Eidelberg et $\mathbf{l}^{8}$ who proposed that such "infected ependymal cells may detach, travel along CSF pathways and implant caudally". This hypothesis could account for the lumbosacral predilection and intrathecal localisation of the inflammatory lesions.

The clinical features in those cases and the present one were remarkably similar (table) and included: pain at onset (lumbar and/or radicular), rapid progression to flaccid paraplegia, absence of major sensory deficit, early and severe global sphincter dysfunction and acute aggravative course leading to death in a few weeks. The only case with prolonged evolution was that of Moskowitz et $a l^{6}$ in which CMV invasion seemed to be limited for a long time to the nervous 
Table Clinical features in the present case and the previously reported ones of CMV myeloradiculopathy

\begin{tabular}{|c|c|c|c|c|c|c|c|}
\hline & $\begin{array}{l}\text { Age* } \\
(y r)\end{array}$ & $\begin{array}{l}\text { Previous } \\
\text { infections }\end{array}$ & $\begin{array}{l}\text { Pain at } \\
\text { onset }\end{array}$ & $\begin{array}{l}\text { Paraplegia } \\
\text { occurrence }\end{array}$ & $\begin{array}{l}\text { Sensory } \\
\text { loss }\end{array}$ & $\begin{array}{l}\text { Sphincterian } \\
\text { dysfunction }\end{array}$ & Duration* \\
\hline Moskowitz et al ${ }^{6}$ & 34 & P. Carinii HSV & + & 1,5 week & stocking gloves & ? & 24 weeks \\
\hline $\begin{array}{l}\text { Bishopric et al } \\
\text { (case 1) }\end{array}$ & 41 & $\begin{array}{l}\text { P. Carinii candidiasis } \\
\text { HSV }\end{array}$ & + & 1 week & 0 & $?$ & 3 weeks \\
\hline $\begin{array}{l}\text { Eidelberg et } a l^{8} \\
\text { (case 1) }\end{array}$ & 34 & $\begin{array}{l}\text { P. Carinii candidiasis } \\
\text { CMV }\end{array}$ & + & 2,5 weeks & $\begin{array}{l}\text { perianal } \\
\text { genital }\end{array}$ & $\begin{array}{l}\text { retention } \\
\text { incontinence }\end{array}$ & 4,5 weeks \\
\hline Jeantils et al ${ }^{9}$ & 43 & P. Carinii & + & 2, 5 weeks & subjectiv & retention & 8 weeks \\
\hline $\begin{array}{l}\text { Singh et al }{ }^{10} \\
\text { (case 1) }\end{array}$ & 37 & P. Carinii & 0 & 2,5 weeks & 0 & incontinence & 4 weeks \\
\hline $\begin{array}{l}\text { Behar et al" } \\
\text { Present case }\end{array}$ & $\begin{array}{l}33 \\
26\end{array}$ & $\begin{array}{l}\text { P. Carinii candidiasis } \\
0\end{array}$ & $\begin{array}{l}0 \\
+\end{array}$ & $\begin{array}{l}2,5 \text { weeks } \\
2 \text { weeks }\end{array}$ & $\begin{array}{l}0 \\
\text { stockings }\end{array}$ & $\begin{array}{l}\text { retention } \\
\text { retention } \\
\text { incontinence }\end{array}$ & $\begin{array}{c}7,5 \text { weeks } \\
4 \text { weeks }\end{array}$ \\
\hline
\end{tabular}

*Duration of illness from presentation to death.

system. However, unlike all the other cases previously reported in which this complication appeared late in the course of the disease, subsequently to various opportunistic infections such as Pneumocystis carinii pneumoniae, HSV infection and/or candidiasis, in the patient described here CMV myeloradiculopathy was the initial manifestation of AIDS.

All cases had meningitis with pleocytosis (50 to 1140 cells) of polymorphonuclear predominance $(57 \%$ to $97 \%$ in the six cases assayed). Viral tests for CMV were usually of poor help, CMV grew from blood or urine in one single case ${ }^{9}$ and blood titres were positive in two cases: $1 / 256^{10}$ and $1 / 32 .{ }^{11} \mathrm{CMV}$ was cultured from CSF in one case only.

The recent finding that 9-(1,3-dihydroxy-2 propoxymethyl)guanine (DHPG) (Ganciclovir) $^{\mathrm{R}}$ is effective in the treatment of CMV infections ${ }^{19}$ has made the early diagnosis of this myeloradiculopathy important. Since viral tests for CMV usually fail to demonstrate active CMV infection of the nervous system (cf. supra), the diagnosis of CMV acute myeloradiculitis has to be made, and the treatment started, on the suggestive, rapidly progressive cauda equina clinical syndrome only.

The authors thank Professor Claude Vedrenne, Doctor René Maunoury and Michèle Peyric for CMV immunostainings, Doctor Catherine Lacroix-Ciaudo for the neuro-muscular biopsy data, Martine Favolini for the histological preparations and Pascal Miele for photography.

This study was supported in part by a grant to Dr Gray from ARSIDA.

\section{References}

1 Centers for Disease Control. Classification system for HTLV-III/LAV infections. MMWR 1986;35:305-8.

2 Petito CK, Cho E-S, Lemann W, Navia BA, Price RW.
Neuropathology of acquired immunodeficiency syndrome (AIDS): an autopsy review. J Neuropathol Exp Neurol 1986;45:635-46.

3 Macher AM, Reichert CM, Strauss SE, Longo DL, Parrillo J, Lane C, Fauci AS. Death in the AIDS patient: role of cytomegalovirus. $N$ Engl J Med 1983;309:1454.

4 Snider WD, Simpson DM, Nielsen S, Gold JWM, Metroka CE, Posner JB. Neurological complications of acquired immune deficiency syndrome: analysis of $\mathbf{5 0}$ patients. Ann Neurol 1983;14:403-18.

5 Gray F, Gherardi R, Keohane C, Favolini M, Sobel A, Poirier J. Pathology of the Central Nervous System in 40 cases of Acquired Immune Deficiency Syndrome (AIDS). Neuropathol Applied Neurobiol 1988;14: 365-80.

6 Moskowitz LB, Gregories JB, Hensley GT, Berger JR. Cytomegalovirus-induced demylination associated with acquired immune deficiency syndrome. Arch Pathol Lab Med 1984;108:873-7.

7 Bishopric G, Bruner J, Butler J. Guillain-Barré syndrome with cytomegalovirus infection of peripheral nerves. Arch Pathol Lab Med 1985;109:1106-8.

8 Eidelberg D, Sotrel A, Vogel H, Walker P, Kleefield J, Crumpacker CS. Progressive polyradiculopathy in acquired immune deficiency syndrome. Neurology 1986;36:912-6.

9 Jeantils V, Lemaître M-O, Robert J, Gaudouen Y, Krivitzky A, Delzant G. Subacute polyneuropathy with encephalopathy in AIDS with human cytomegalovirus pathogenicity. Lancet 1986;ii: 1039.

10 Singh BM, Levine S, Yarrish RL, Hyland MJ, Jeanty D, Wormser GP. Spinal cord syndrome in the acquired immuned deficiency syndrome. Acta Neurol Scand 1986;73:590-8.

11 Behar R, Wiley C, McCutchan JA. Cytomegalovirus polyradiculoneuropathy in acquired immune deficiency syndrome. Neurology 1987;327:557-61.

12 Dalakas MC, Pezeshkpour GH. Neuromuscular Diseases Associated with Human Immunodeficiency Virus infection. Ann Neurol 1988;23(suppl):S38-S48.

13 Gray F, Gherardi R, Scaravilli F. The neuropathology of the acquired immune deficiency syndrome (AIDS): a review. Brain 1988;111:245-66.

14 Parry GJ. Peripheral neuropathies associated with 
human immunodeficiency virus infection. Ann Neurol 1988;23(suppl):S49-S53.

15 Cornblath DR, McArthur JC, Kennedy PGE, Witte AS, Griffin JW. Inflammatory demyelinating peripheral neuropathies associated with human T-cell lymphotropic virus type III infection. Ann Neurol 1987;21:32-40.

16 Yanagisawa N, Toyokura Y, Shiraki H. Double encephalitis with herpes simplex virus and cytomegalovirus in an adult. Acta Neuropathol (Berl) 1975;33:153-64.

17 Tucker T, Dix RD, Katzen C, Davis RL, Schmidley JW. Cytomegalovirus and Herpes simplex virus ascending myelitis in a patient with acquired immune deficiency syndrome. Ann Neurol 1985;18:74-9.

18 Kleihues P, Lang W, Burger PC, Budka H, Vogt M, Maurer R, Lüthy R, Siegenthaler W. Progressive Diffuse Leukocenephalopathy in Patients with Acquired Immune Deficiency Syndrome (AIDS). Acta Neuropathol (Berl) 1985;68:333-9.

19 Collaborative DHPG Treatment Study Group. Treatment of serious cytomegalovirus infections with 9-(1,3dihydroxy-2propylmethyl)guanine in patients with AIDS and other immunodeficiencies. $N$ Engl $J$ Med 1986;314:801-5.

Armand Trousseau and Parkinson's disease

Armand Trousseau (1801-1867) was a distinguished French physician who worked in the Hôpital St Antoine in Paris. Best known for his description of venous thrombosis as a possible signal of a visceral cancer, he observed this in himself, confirming his suspicion of gastric carcinoma.

Of neurological interest and importance is his contribution to Parkinson's disease in his Lectures on Clinical Medicine.' He described (1861, later translated in 1868) rigidity, a sign Parkinson did not pay attention to, and he explained the scelotyrbe festinans: "as his centre of gravity is thus displaced, he is obliged to run after himself, as it were, so that he keeps trotting and hopping on." Trousseau also described the progressive slowing of repeated hand opening, the first clear account of bradykinesia. Although James Parkinson had said "the senses and intellects being uninjured", Trousseau commented: "the intellect. . gets weakened at last; the patient loses his memory, and his friends notice soon that his mind is not as clear: precocious caducity sets in." Trousseau was a realist. He had, he said, not cured a single patient with medicaments; pneumonia was the common ending.

JMS PEARCE

\section{Reference}

1 Trousseau A. Lecture XV. Senile trembling and paralysis agitans. In: Lectures on Clinical Medicine Delivered at the Hôtel Dieu, Paris. P V Bazire (trans). London, New Sydenham society, 1868. 